\title{
EFEK PEMBERIAN SEDUHAN SELEDRI (APIUM GRAVEOLENS L.)TERHADAP KADAR ASAM URAT PADA TIKUS PUTIH JANTAN STRAIN WISTAR (RATTUS NORVEGICUS) HIPERURISEMIA
}

\author{
Reni Deviandra ${ }^{1}$, Fathiyah Safitri ${ }^{2}$, Djaka Handaja ${ }^{3}$
}

Fakultas Kedokteran Universitas Muhammadiyah Malang, Jalan Bendungan Sutami No. 188A, Kota Malang, Kode Pos 65144, Indonesia.

\begin{abstract}
ABSTRAK
Efek Pemberian Seduhan Seledri (Apium graveolens L.)Terhadap Kadar Asam Urat Pada Tikus Putih Jantan Strain Wistar (Rattus norvegicus) Hiperurisemia. Latar Belakang: Salah satu jenis tanaman yang diduga dapat menurunkan kadar asam urat adalah seledri. Seledri mengandung flavonoid dan 3-n butylphtalide (3nB) dapat menurunkan kadar asam urat dengan menghambat kerja enzim xantin oksidase. Tujuan: Penelitian ini bertujuan untuk mengetahui pengaruh seduhan seledri (Apium graveolens L.) terhadap penurunan kadar asam urat pada tikus putih jantan hiperurisemia. Metode Penelitian: Menggunakan eksperimental murni, dengan rancangan Randomized Post Test Control Group Design. Sampel penelitian dibagi menjadi 5 kelompok. Kelompok I: Kontrol positif (Saripati hati ayam mentah $3 \mathrm{ml} / 150 \mathrm{grBB}$ selama 21 hari + pakan normal selama 7 hari), II, III dan IV: diberikan Saripati hati ayam mentah $3 \mathrm{ml} / 150 \mathrm{grBB}$ selama 21 hari + seduhan seledri dengan dosis 50,100,150mg/ekor/hari selama 7 hari, V: Kontrol negatif (Pakan normal selama 28 hari). Pengukuran kadar asam urat dengan menggunakan metode kolometrik enzimatik. Hasil: Hasil pengukuran asam urat kelompok dengan pemberian seduhan seledri dosis $150 \mathrm{mg} /$ ekor/hari menunjukkan kadar asam urat paling rendah $(4,679 \pm 0,687)$ dibanding dengan kelompok kontrol positif menunjukkan kadar asam urat paling tinggi $(11,563 \pm 1,541)$. Kesimpulan: Ada hubungan antara dosis seduhan seledri (Apium graveolens L.) terhadap kadar asam urat pada tikus putih jantan (Rattus Norvegicus) hiperurisemia.
\end{abstract}

Kata Kunci: Seledri, Hiperurisemia, Kadar Asam Urat, Saripati Hati Ayam,

\begin{abstract}
The Effect of Water Steeping Celery (Apium graveolens Linn.) on Level of Uric Acid White Male Rat (Rattus norvegicus) Hyperuricemia. Introduction: One type of plant that could be expected to reduce level of uric acid is celery (Apium graveolens L.). Celery contains flavonoid and 3-n butilphtalide (3nB) expected to reduce level of uric acid by inbibiting the action of the xanthine oxidase. Objective: This study was aimed to determine the effect of steeping celery (Apium graveolens L.) to the level of uric acid on white male rat hyperuricemia. Method: This study was true experimental, by using randomized post test control group design. The sample of this study was divided into 5 groups. Group I: positive control (an nectars of raw chicken liver $3 \mathrm{ml} / 150 \mathrm{mg}$ body weight for 21 days + normal feed for 7 days) Group II, III and IV: was given an nectars of raw chicken liver $3 \mathrm{ml} / 150 \mathrm{mg}$ body weight for 21 days + celery steeping with a dose: 50, 100, $150 \mathrm{mg} /$ head/day for 7 days, Group $V$ : negative control (normal feed for 28 days). The levels measurement of uric acid by using ensymatic colorimetric method. Result: The results measurement of uric acid group with steeping celery dose $150 \mathrm{mg} / \mathrm{head} /$ day showed the levels lowest of uric acid $(4,679 \pm 0,687)$ compared with positive control group showed the highest uric acid levels $(11.563 \pm 1.541)$. Conclusion: Steeping celery (Apium graveolens L.) is known to decrease the levels of uric acid on white male rat (Rattus norvegicus) byperuricemia.
\end{abstract}

Key words : Celery, Hyperuricemia, Uric Acid Levels, Nectars Chicken Liver

\section{PENDAHULUAN}

Asam urat merupakan asam yang berbentuk kristalkristal yang merupakan hasil akhir dari metabolisme purin (bentuk nukleoprotein). Patokan untuk menentukan hiperurisemia yaitu kadar asam urat lebih dari $7,0 \mathrm{mg} / \mathrm{dl}$ pada laki-laki dan lebih dari $6,0 \mathrm{mg} / \mathrm{dl}$ pada perempuan. Dalam keadaan normal terjadi keseimbangan antara pembentukan dan degradasi nukleotida purin serta kemampuan ginjal dalam mengekskresikan asam urat.
Apabila terjadi kelebihan pembentukan (overproduction) atau penurunan ekskresi (underexcretion) atau keduanya maka akan terjadi peningkatan konsentrasi asam urat darah yang disebut dengan hiperurisemia (Hensen, 2007; Wisesa dan Suastika, 2009; Wortman, 2009; Putra, 2007). Belum ada data pasti, kejadian hiperurisemia pada masyarakat Indonesia. 
Penelitian yang dilakukan oleh Indrawan (2005) pada penduduk kota Denpasar, Bali mendapatkan prevalensi hiperurisemia sebesar 18,2\%. Prevalensi hiperurisemia di masyarakat dan berbagai kepustakaan barat sangat bervariasi, diperkirakan antara 2,3-17,6\%, sedangkan kejadian gout bervariasi antara 0,16-1,36\% (Kelley dan Wortman, 1997). Di China pada tahun 2006, Nan dkk (2006) mendapatkan prevalensi hiperurisemia sebesar $25,3 \%$ dan gout sebesar $0,36 \%$ pada orang dewasa usia $20-74$ tahun. Terapi yang dapat digunakan untuk mengatasi hiperurisemia adalah golongan urikosurik dan inhibitor xantin oksidase. Obatobat urikosurik seperti probenesid dan sulfinpirazone akan meningkatkan klirens ginjal untuk asam urat dengan cara menghambat reabsorpsi tubular dari asam urat.

Saat ini banyak dikembangkan tanaman obat yang diduga dapat menurunkan asam urat. Sedangkan golongan inhibitor xantin oksidase bekerja dengan cara menghambat perubahan hipoxantin menjadi xantin dan xantin menjadi asam urat. Akumulasi allopurinol dan metabolitnya akan menimbulkan reaksi toksik tetapi reaksi ini jarang terjadi namun jika terjadi dapat berakibat fatal. Reaksi toksik yang ditimbulkan antara lain ditandai dengan timbulnya skin rash, selain itu juga dapat terjadi hepatitis, demam, eosinofilia, eritematus, serta dapat pula menyebabkan berkembangnya penyakit ginjal. Berdasarkan studi yang dilakukan terhadap 120 pasien menunjukkan bahwa sebanyak lima orang pasien mengalami efek samping dari terapi allopurinol yaitu empat orang mengalami skin rash dan satu orang mengalami sindroma hipersensitivitas allopurinol (Hawkins and Rahn, 2006; Mellado, et al., 2001). Oleh sebab itu tujuan penelitian ini dilakukan adalah untuk mengetahui pengaruh seduhan seledri (Apium graveolens L.) terhadap kadar asam urat pada tikus jantan hiperurisemia, sedangkan tujuan khususnya adalah untuk mengetahui dosis seduhan seledri (Apium graveolens $L$.) yang memiliki pengaruh paling efektif terhadap penurunan kadar asam urat serum pada tikus jantan hiperurisemia. Salah satu tanaman obat tersebut adalah seledri. Infus daun seledri dengan kadar $10 \%$ sebanyak 5 $\mathrm{ml} / \mathrm{kg}$ bb akan memberikan efek penurunan kadar asam urat darah kera secara nyata (Dalimarta, 2000). Mengingat tanaman obat bersifat kompleks dan organis yang cocok untuk tubuh yang bersifat kompleks dan organis, sehingga tanaman obat dapat disetarakan dengan makanan, suatu bahan yang dikonsumsi dengan maksud merekonstruksi organ yang rusak.

Berbagai penelitian telah berhasil membuktikan bahwa beberapa obat bahan alam sangat efektif untuk digunakan pada kondisi hiperurisemia. Di samping itu, obat yang berasal dari bahan alam ini relatif lebih aman, murah dan mudah diperoleh, karena dapat disediakan sendiri di rumah dengan proses pembuatan yang sederhana (Florakita, 2009). Adapun manfaat penelitian secara akademis adalah untuk memberikan informasi yang dapat digunakan sebagai dasar untuk penelitian lebih lanjut mengenai efek penurunan kadar asam urat seduhan seledri, mengembangkan ilmu pengetahuan, terutama mengenai bahan alam yang dapat digunakan sebagai pengobatan alternatif, sedangkan tujuan secara klinis adalah melalui penelitian ini diharapkan dapat diperoleh pilihan terapi adjuvant dengan menggunakan bahan alam di sekitar kita dengan biaya yang terjangkau masyarakat luas.
Dalam tanaman obat seledri, terdapat kandungan flavonoid dan $3-n$ butylphthalide $(3 \mathrm{nB})$ yang diduga mempunyai mekanisme kerja untuk menghambat pembentukan asam urat. Aktivitas flavonoid dan 3-n butylphthalide $(3 \mathrm{nB})$ sebagai penurun kadar asam urat melalui proses penghambatan kerja enzim xantin oksidase (Kristanti, 2003; Murray, 2004). Berdasarkan beberapa penelitian tersebut, peneliti ingin meneliti lebih lanjut mengenai efek pemberian seduhan seledri terhadap penurunan kadar asam urat pada tikus putih jantan strain wistar dan memberikan informasi dengan dasar bukti yang dapat dipertanggungjawabkan secara ilmiah sehingga dapat digunakan sebagai terapi alternatif.

\section{METODE}

Penelitian ini merupakan penelitian eksperimental murni (true exsperimen) yang dilakukan di dalam laboratorium dengan menggunakan hewan coba tikus putih jantan strain wistar untuk keperluan eksplorasi. Design penelitian yang digunakan adalah Post Test Control Group Design, yaitu dilakukan pengamatan/pengukuran kadar asam urat sesudah perlakuan (Rofieq, 2001).

Penelitian dilakukan selama 32 hari di Laboratorium Kimia Kampus III Universitas Muhammadiyah Malang. Populasi yang digunakan dalam penelitian ini adalah tikus putih jantan (Rattus norvegicus) dewasa strain wistar berusia 23 bulan. Sampel yang dipakai dalam penelitian ini adalah tikus putih jantan (Rattus norvegicus) strain wistar, dewasa dengan usia 2-3 bulan. Dalam penelitian ini terdapat 5 kelompok perlakuan terhadap tikus puth (Rattus norvegicus L.) strain wistar yaitu satu kelompok kontrol negatif (tikus yang tanpa diberi saripati hati ayam dan tanpa seduhan seledri), satu kontrol positif (tikus yang diberi saripati hati ayam, tanpa seduhan seledri), dan tiga kelompok perlakuan (tikus yang mendapat saripati hati ayam dan seduhan seledri dalam tiga dosis yang berbeda). Teknik pengambilan sampel yang digunakan dalam penelitian ini adalah Completely Randomized Design.

Alat-alat yang digunakan untuk pembuatan jus hati adalah timbangan analitik, pisau, mortal martil, gelas ukur, dan spatula. Alat yang digunakan untuk uji hiperurisemia adalah kandang metabolik lengkap dengan tempat makan dan minum timbangan analitik syringe, kanule, gelas ukur, gelas beker, serta pipet tetes. Sedangkan alat untuk analisis kadar asam urat dalam serum adalah mikrohematokrit, pipet tetes, tabung eppendorf $2 \mathrm{ml}$, spektrofotometer dengan panjang gelombang $500-550 \mathrm{~nm}$, mikropipet, sentrifuge, tabung kuvet. Mengenai bahan yang digunakan yaitu hewan coba sebanyak 25 ekor tikus putih jantan strain wistar usia 2-3 bulan dengan berat badan \pm 150 gram, seduhan seledri (Apium graveolens L.), saripati hati ayam. Sedangkan bahan analisis kadar asam urat adalah reagen asam urat yaitu uric acid FS* TOOP produksi Diasys, pakan tikus, dan aquades.

\section{HASIL DAN PEMBAHASAN}

Dalam pengujian pemberian seduhan seledri (Apium graveolens L.) terhadap kadar asam urat serum tikus putih jantan (Rattus Norvegicus) strain wistar, digunakan bentuk 
seduhan seledri dengan variasi dosis yang berbeda untuk masing-masing perlakuan yaitu dosis $50 \mathrm{mg} /$ ekor/hari, 100 $\mathrm{mg} /$ ekor/hari, $150 \mathrm{mg} /$ ekor/hari yang diberikan sehari sekali selama 7 hari. Sebagai pembanding yaitu kontrol negatif dengan pemberian pakan normal dan kontrol positif dengan pemberian saripati hati ayam selama 21 hari.

Pada penelitian ini, pemberian saripati hati ayam selama 21 hari bertujuan untuk mendapatkan kondisi hiperurisemia pada setiap perlakuan diberikan seduhan seledri (Apium graveolens L.) dengan tiga variasi dosis sebagai faktor perlakuan yaitu 50 $\mathrm{mg} /$ ekor/hari; $100 \mathrm{mg} /$ ekor/hari; $150 \mathrm{mg} /$ ekor/hari.

Tabel 1. Rerata Kadar Asam Urat Serum Pada Pengamatan Hari ke-28 TikusPutih Jantan (Rattus Norveqicus) Strain Wistar Hiperurisemia

\begin{tabular}{|c|c|c|c|}
\hline \multirow[t]{2}{*}{ Perlakuan } & \multicolumn{3}{|c|}{ Kadar asam Urat (mg/dl) } \\
\hline & $X$ & \pm & SD \\
\hline $\begin{array}{l}\text { Kontrol positif (Saripati hati ayam mentah } \\
3 \mathrm{ml} / 150 \mathrm{grBB} \text { tikus. Tanpa seduhan } \\
\text { seledri) }\end{array}$ & 11.563 & \pm & 1,541 \\
\hline $\begin{array}{l}\text { Saripati hati ayam mentah } 3 \mathrm{ml} / 150 \mathrm{grBB} \\
\text { tikus I seduhan seledri } 50 \mathrm{mg} / \mathrm{ekor} / \mathrm{hari} \\
\text { (Perlakuan 1) }\end{array}$ & 9.030 & + & 0,484 \\
\hline $\begin{array}{l}\text { Saripati hati ayam mentah } 3 \mathrm{ml} / 50 \mathrm{grBB} \\
\text { tikus + seduhan seledri } 100 \mathrm{mg} / \mathrm{ekor} \text { hari } \\
\text { (Perlakuan } 2 \text { ) }\end{array}$ & 7.459 & \pm & 0.626 \\
\hline $\begin{array}{l}\text { Saripati hati ayam mentah } 3 \mathrm{ml} / 150 \mathrm{grBB} \\
\text { tikus + scduhan scledri } 150 \mathrm{mg} \text { ckor hari } \\
\text { (Perlakuan } 3 \text { ) }\end{array}$ & 4.679 & \pm & 0,687 \\
\hline $\begin{array}{l}\text { Kontrol negatif ( Tanpa Saripati hati ayam } \\
\text { mentah } 3 \mathrm{ml} / 150 \text { grBB tikus \& Tanpa } \\
\text { seduhan seledri) }\end{array}$ & 2.894 & + & 0.478 \\
\hline
\end{tabular}

\section{(Data primer, 2011)}

Berdasarkan pengamatan, nilai kadar asam urat serum akhir tikus pada hari ke-28 menunjukan adanya perbedaan kadar asam urat dari variasi dosis pemberian seduhan seledri terhadap kadar asam urat serum tikus putih jantan (Rattus Norvegicus) strain wistar hiperurisemia. Hasil pengamatan kadar asam urat hari ke-28 tampak pada Tabel 1. Pada kelompok perlakuan tikus I dengan pemberian seduhan seledri sebanyak $50 \mathrm{mg} /$ ekor/hari tikus rata-rata kadar asam urat serum tikus adalah $9,030 \mathrm{mg} / \mathrm{dl}$ dengan dosis $100 \mathrm{mg} /$ dl/ekor (kelompok perlakuan II) didapatkan rata-rata kadar asam urat serum tikus adalah $7,459 \mathrm{mg} / \mathrm{dl}$ dan dengan dosis $150 \mathrm{mg} /$ ekor/dl pada kelompok perlakuan III diketahui rata-rata kadar asam urat menurun mencapai normal yaitu 4,679 mg/dl.

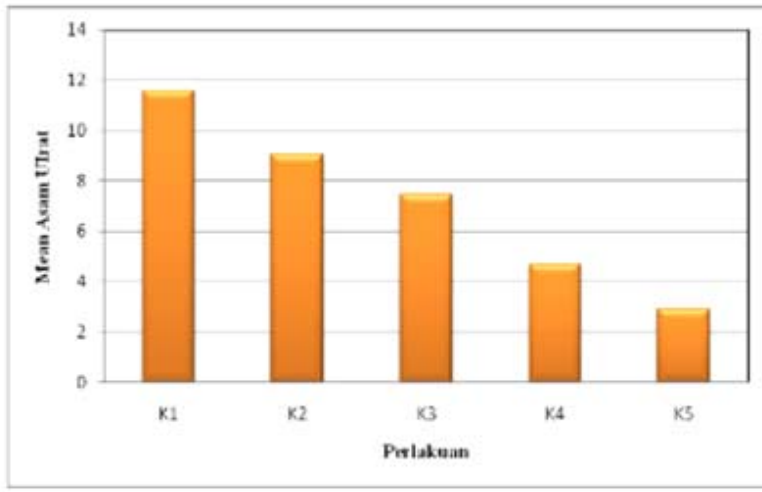

Gambar 1. Grafik Blox Plot Kadar Asam Urat Serum Tikus Putih Jantan (Rattus Norvegicus) Strain Wistar Hiperurisemia.
Data pada grafik blok plot diatas menunjukan bahwa terjadi penurunan yang nyata terhadap kadar asam urat yang diberi seduhan seledri dibandingkan kelompok kontrol positif. Uji statistika perbandingan berganda Tukey HSD antara kelompok kontrol positif dengan kelompok perlakuan masing-masing dosis menunjukan adanya perbedaan yang bermakna terhadap kadar asam urat serum tikus hiperurisemia ( $p$ masing-masing $=0,000$ ).

Data yang diperoleh kemudian di analisa Normalitas dan Homogenitas untuk mengetahui apakah data layak untuk diuji Anova. Hasil uji Normalitas (lampiran 1) menunjukkan bahwa pada kolom uji Kolgomorov Smirnov, nilai $p=0,987>(p>0,05)$ yang berdistribusi data asam urat serum tikus putih bersifat homogen. Hasil Uji Homogenitas (lampiran 1) menunjukkan bahwa $\mathrm{p}=0,869(\mathrm{p}>0,05)$ yang berarti varian data kadar asam urat serum darah tikus putih bersifat homogeny. Selanjutnya dapat disimpulkan bahwa kadar asam urat serum dapat dilanjutkan untuk uji Anova. Hasil uji Anova menunjukan nilai $p=0,000(p<0,05)$ yang berarti terdapat pengaruh yang bermakna terhadap pengaruh sangat bermakna terhadap kadar asam urat serum tikus putih. Hasil uji lanjutan Honesty Significant Differences (HSD) $1 \%$ (lampiran 1) menerangkan bahwa perlakuan seduhan daun seledri mampu menurunkan kadar asam urat serum. Tabel hasil uji lanjut Honesty Significant Differences (HSD) 1\% dapat dilihat pada tabel berikut.

\section{Tabel 2. Hasil Uji Lanjut Honesty Significant Differences (HSD) 1\% Asam Urat Serum}

\begin{tabular}{lcc}
\multicolumn{1}{c}{ Perlakuan } & Rerata & Notasi \\
\hline $\begin{array}{l}\text { Kontrol positif (Saripati hati ayam } \\
\text { mentah } 3 \text { mL/150grBB tikus, Tanpa }\end{array}$ & 11.563 & A \\
seduhan seledri) & & \\
$\begin{array}{l}\text { Saripati hati ayam mentah 3 } \\
\text { mL/150grBB tikus + scduhan scledri }\end{array}$ & 9.030 & B \\
$\begin{array}{l}50 \text { mg/ekor/hari (Perlakuan 1) } \\
\text { Saripati hati ayam mentah 3 } \\
\text { mL/150grBB tikus + seduhan seledri } \\
100 \text { mg ckor/hari (Perlakuan 2) }\end{array}$ & 7.459 & B \\
$\begin{array}{l}\text { Saripati hati ayam mentah 3 } \\
\text { mL/150grBB tikus + seduhan seledri } \\
150 \text { mg ekor/hari (Perlakuan 3) }\end{array}$ & & \\
\hline
\end{tabular}

Keterangan : angka yang diikuti huruf yang sama berarti tidak berbeda nyata pada uji Tukey $1 \%$.

Sedangkan pada uji korelasi menunjukan bahwa nilai Sig $(1$-tailed $)=0,000$ kurang dari $\mathrm{p}(0,01)$ yang berarti terdapat korelasi antara perlakuan dan kadar asam urat yang bermakna. Korelasi yang terjadi adalah korelasi yang berbanding terbalik, artinya kenaikan dosis menyebabkan menurunnya nilai kadar asam urat serum tikus putih. Hal ini terlihat dari nilai pearson correlation $=-0,944$.

Persamaan tersebut sesuai dengan tabel anova regresi dimana nilai sig $=0,000<\mathrm{p}(0,05)$ yang berarti model regresi cocok secara bermakna. Hal tersebut didukung pula pada uji t tabel coefficient yang menunjukkan bahwa nilai Sig $($ constant $)=0,000$ dan nilai sig $($ dosis $)=0,000$ yang berarti kurang dari nilai p (0,05). Grafik Regresi yang menyatakan hubungan antara dosis seduhan seledri (mg/ekor/hari) dengan kadar asam urat serum tikus putih sebagai berikut: 


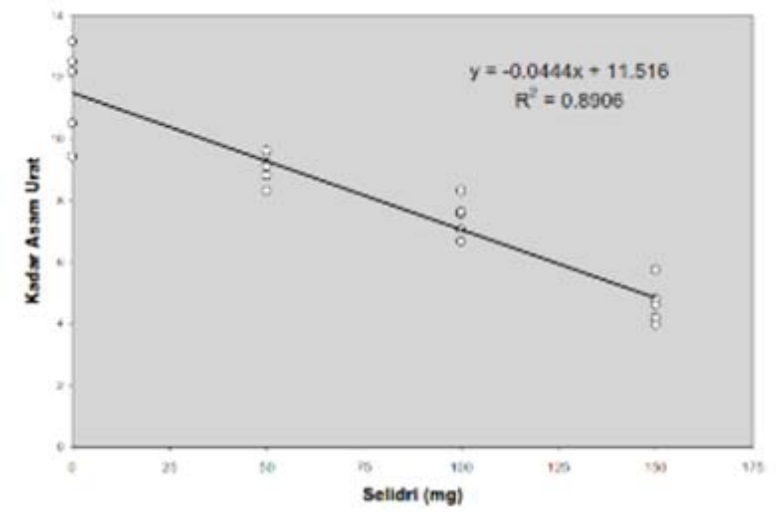

Gambar 2. Analisis regresi antara dosis seduhan seledri dengan kadar asam urat serum tikus hari ke-28

Data kelompok perlakuan seduhan seledri 50, 100, dan $150 \mathrm{mg} /$ ekor/hari menunjukkan bahwa makin tinggi seduhan seledri yang diberikan, ada kecenderungan kadar asam urat serum tikus hiperurisemia semakin rendah. Analisis regresi antara dosis seduhan seledri dan kadar asam urat serum tikus (gambar 5.2) menunjukan bahwa dosis berpengaruh negatif terhadap kadar asam urat serum tikus, yang berarti bahwa makin tinggi dosis seduhan seledri yang diberikan, semakin rendah kadar asam urat serum tikus ( $\mathrm{p}=0,000 ; \mathrm{R} 2=0,891)$.

Penelitian ini telah membuktikan bahwa pemberian seduhan seledri dapat menurunkan kondisi hiperurisemia pada tikus. Perlakuan saripati hati ayam pada kelompok I (kontrol positif), perlakuan II, III, dan IV dihentikan yang dilanjutkan dengan perlakuan seduhan seledri selama 7 hari (Pada Pelakuan II, III dan IV). Pada tikus jantan strain

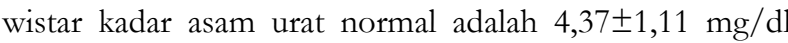
sedangkan pada tikus betina sebesar 2,92 $\pm 0,241 \mathrm{mg} / \mathrm{dl}$ (Taconic Technical Laboratory, 1998).

Pada penelitian ini menggunakan hewan uji tikus putih jantan galur Wistar berumur 2-3 bulan dengan berat badan \pm 150 gram. Tikus putih digunakan karena memiliki kemiripan dengan manusia dalam hal fisiologi, anatomi, nutrisi, patologi atau metabolisme. Jenis kelamin jantan digunakan karena memiliki kecepatan metabolism yang sedikit terpengaruh oleh perubahan hormonal. Galur Wistar digunakan karena galur ini memenuhi syarat sebagai hewan uji untuk perlakuan hiperurisemia (Hakim, 2002).

Hiperurisemia disebabkan melalui tiga faktor. Pertama, penurunan ekskresi asam urat dalam tubuh. Penurunan ekskresi asam urat terjadi pada 90\% kasus yang disebabkan karena idiopatik primer, penurunan fungsi renal, penghambatan sekresi asam urat (ketoasidosis, laktatasidosis), hipertensi, obat-obatan (salisilat dosis rendah, diuretik, pirazinamid, ethambutol, warfarin, siklosporin, teofilin, levodopa, asam nikotinat, alkohol). Kedua, adanya peningkatan produksi asam urat. Peningkatan produksi asam urat terjadi pada 10\% kasus yang disebabkan karena aktivitas sintesis fosforibosil pirofosfat yang berlebihan, defisiensi guanin fosforibosil transferase, konsumsi purin yang berlebihan, perubahan bentuk nukleotida (psoriasis, myeloproliferatif, limfoproliferatif), peningkatan degradasi Adenosine trifosfat. Ketiga, kombinasi kedua mekanisme tersebut (Choi, 2005). Kondisi hiperurisemia pada penelitian ini diinduksi dengan pemberian saripati hati ayam $3 \mathrm{ml} /$ 150grBB selama 21 hari. Saripati hati ayam digunakan sebagai agen hiperurisemik dalam penelitian ini karena mengandung bahan pangan dengan kandungan purin tinggi.

Hati ayam merupakan golongan bahan pangan sumber purin tinggi yang mengandung purin sebesar $150-800 \mathrm{mg} /$ 100g. Hati ayam mengandung purin $243 \mathrm{mg}$ per 100 gram. Purin yang besaral dari konsumsi bahan pangan dapat mempengaruhi jumlah asam urat dalam tubuh. Mekanisme pembentukan asam urat dari protein bermula dari degradasi diet protein menjadi asam amino. Beberapa asam amino ini selanjutnya didegradasi membentuk glutamate. Glutamate yang terbentuk selanjutnya dimetabolisir membentuk aketoglutarat, aspartat, dan sebagian membentuk glutamine. Ketika glutamine bereaksi dengan fosforibosil pirofosfat (PRPP) yang merupakan suatu gula derivative dari ribose-5-fosfat maka akan terbentuk fosforibosalamin. Fosforibosalamin merupakan prekusor bagi pembentukan asam nukleat purin. Melalui serangkaian reaksi yang melibatkan penambahan asam amino glisin, glutamine, aspartat, dan koenzim $\mathrm{N}^{10} 53$ formil-THF (tetra hidro folat) akan terbentuk inosin monofosfat (IMP). IMP merupakan prekursor dalam sintesis purin, IMP ini selanjutnya diubah bentuk menjadi AMP dan GMP maupun bentuk basa bebasnya, adenine dan guanine. Melalui mekanisme regulasi sel, purin yang terbentuk ini selanjutnya dimetabolisir untuk keperluan diantaranya sintesis senyawa berenergi tinggi seperti ATP, bahan baku dalam pelaksanaan ekspresi genetik (sintesis protein) ataupun transformasi genetik, dan beberapa purin dikatabolisme membentuk asam urat (Mycek et al, 2001; Nidiana, 2010)

Berdasarkan hasil penelitian dan analisa data menunjukan bahwa pemberian seduhan seledri dapat menurunkan kadar asam urat serum darah tikus yang diinduksi saripati hati ayam. Pada penelitian ini digunakan kontrol negatif (Tanpa Saripati hati ayam mentah $3 \mathrm{ml} /$ $150 \mathrm{grBB}$ tikus \& Tanpa seduhan seledri) dan Kontrol positif (Saripati hati ayam mentah $3 \mathrm{ml} / 150 \mathrm{grBB}$ tikus, Tanpa seduhan seledri) untuk mengontrol hasil yang diperoleh dari kelompok perlakuan serta bertujuan memberikan validitas yang tinggi dalam suatu penelitian. Kontrol negatif selain bermanfaat sebagai base line. Kontrol positif bertujuan: (1) untuk mengkonfirmasi validitas metode dan prosedur penelitian, (2) sebagai rujukan bagi senyawa, obat baru atau bahan alam yang sedang diteliti sehingga ditemukan potensi relatif terhadap obat tersebut (Hakim, 2002). Pada kelompok tikus yang diberi seduhan seledri selama 7 hari (perlakuan II, III dan IV) dapat dilihat adanya kadar asam urat serum tikus hiperurisemia menurun secara signifikan dengan ditunjukan kadar asam urat serum paling rendah pada dosis 3 (Perlakuan IV) yaitu pemberian seduhan seledri sebanyak $150 \mathrm{mg} /$ ekor/hari dibanding pada dosis 50mg/ekor/hari (Perlakuan II) dan dosis 100mg/ ekor/hari (Perlakuan III). Hal ini diduga karena seduhan seledri mengandung flavonoid dan 3-n butilphthalide (3nB) sebagai antioksidan sehingga dapat menghambat kerja enzim xantin oksidase yang dapat menyebabkan metabolisme purin yang membentuk asam urat tidak terjadi. Seledri mengandung flavonoid, saponin, tannin 1\%, minyak atsiri $0,033 \%$, flavoglukosida (apiin), apigenin, kolin, lipase, asparagin, zat pahit, 
vitamin (A, B, dan C). Setiap $100 \mathrm{~g}$ herba seledri mengandung air sebanyak $93 \mathrm{ml}$, protein $0,9 \mathrm{~g}$, lemak 0,1 $\mathrm{g}$, karbohidrat $4 \mathrm{~g}$, serat $0,9 \mathrm{~g}$, kalsium $50 \mathrm{mg}$, besi $1 \mathrm{mg}$, fosfor $40 \mathrm{mg}$, yodium $150 \mathrm{mg}$, kalium $400 \mathrm{mg}$, magnesium $85 \mathrm{mg}$, vitamin A $130 \mathrm{IU}$, vitamin C $15 \mathrm{mg}$, riboflavin 0,05 $\mathrm{mg}$, tiamin 0,03 $\mathrm{mg}$, dan nikotinamid 0,4 mg. Akar mengandung asparagin, manit, zat pati, lendir, minyak atsiri, pentosan, glutamin, dan tirosin. Biji mengandung apiin, minyak menguap, apigenin, dan alkaloid. Apigenin berkhasiat hipotensif (Dalimartha, 2000). Aktivitas hipourisemik seduhan seledri karena diduga kandungan senyawa aktif antara lain yang telah diketahui flavonoid dan 3-n butilphthalide $(3 \mathrm{nB})$. Senyawa tersebut menghambat pembentukan asam urat dengan cara menghambat enzim xantin oksidase sehingga kadar asam urat dalam serum akan menurun. Senyawa flavonoid yang terkandung dalam seledri termasuk turunan golongan flavon dan flavonol (Ashari, 2005; Ixoranet, 2007; Kristanti, 2003).

Xantin oksidase mempunyai fungsi katalisis mengubah hipoxantin menjadi xantin maupun xantin menjadi asam urat, selain telah ditemukan fungsi lain dari enzim ini dalam mengkatalisis reduksi nitrat dan nitrit menjadi nitrit oksida dan sekaligus menyebabkan pembentukan radikal superoksida yang dapat menyebabkan peradangan (Bodamyali et al, 2002; Millar et al, 2002) Enzim xantin oksidase mengakatalisis purin menjadi asam urat. Jen at al (2000) melaporkan hubungan antara struktur flavonoid dengan aktivitasnya sebagai inhibitor xantin oksidase disebabkan karena adanya gugus hidroksil (gugus-OH) pada C-5 dan C-7 dan ikatan rangkap antara C-2 dan C-3. Adanya ikatan rangkap pada flavonoid memungkinkan untuk melangsungkan reaksi adisi (oksidasi oleh xantin oksidase), adanya ikatan rangkap pada atom C-2 dengan C-3 akan mengakibatkan posisi ring $\mathrm{B}$ co-planar terhadap ring $\mathrm{A}$ sehingga lebih memudahkan dalam berinteraksi dengan enzim xantin oksidase. Selain itu gugus hidroksil yang terdapat pada flavonoid turut berperan dalam memberikan efek penghambatan (Cos et al, 1998). Beberapa senyawa bioaktif asam tumbuhan ketika ditambahkan ke dalam system reaksi enzimatis dapat berperan sebagai activator, yang berarti dapat meningkatkan laju reaksi pembentukan produk dan beberapa justru dapat menyebabkan penurunan laju reaksi (inhibitor) (Boyer, 1970). Senyawa bahan alam seperti flavonoid telah diketahui bersifat inhibitor bagi enzim xantin oksidase. Mekanisme tipe penghambatan yang terjadi umumnya mengarah pada jenis inhibisi kompetitif. Flavonoid mampu menghambat enzim xantin oksidase karena adanya kemiripan struktur antara flavonoid dengan xantin (substrat) (Massey et al, 1970; Price dan Stevens, 1996). Berdasarkan hasil analisis diketahui bahwa pemberian seduhan seledri yang mengandung flavonoid dan 3-n butilphthalide $(3 \mathrm{nB})$ memberikan pengaruh secara signifikan terhadap penurunan kadar asam urat serum tikus hiperurisemia yang diinduksi saripati hati ayam dengan $\mathrm{p}<$ 0,05 . Penelitian ini menunjukkan adanya hubungan yang kuat yaitu terbukti dengan pengaruh dosis air seduhan daun sirih terhadap kadar asam urat serum tikus putih sebesar ( $\mathrm{r}=-0,944 ; \mathrm{Sig}=000<0,05 ; \mathrm{R}=0,891)$. Ini berarti bahwa $89 \%$ kandungan kimia dalam seledri mampu menurunkan kadar asam urat serum darah tikus.
Pemberian dosis seduhan seledri diberikan dalam tiga variasi dosis yang berbeda untuk mengetahui dosis mana yang paling efektif menghambat kenaikan kadar asam urat serum tikus. Berdasarkan penelitian yang telah dilakukan diketahui bahwa dosis paling efektif yaitu dosis yang paling tinggi yang mampu memberikan hasil yang paling mendekati normal adalah kelompok perlakuan IV yaitu pemberian seduhan seledri sebanyak $150 \mathrm{mg} /$ ekor/dl. Dosis ini bila dikonversikan untuk manusia maka akan didapatkan dosis volume besar yaitu $6 \mathrm{mg} / 150 \mathrm{ml}$. Kemungkinan dikarenakan perhitungan dosis yang kurang tepat. Dari hasil uji regresi (gambar 5.2) ditemukan persamaan regresi yaitu y = $0.0444 \mathrm{x}+11.516$ dengan nilai koefisien determinasi $\mathrm{R}^{2}=0,891$. Dari persamaan regresi kadar normal $=4,37 \mathrm{mg} /$ dl (Taconic Technical Laboratory, 1998) bisa dicapai pada dosis 160, $945 \mathrm{mg} / \mathrm{ekor} /$ hari. Hasil ini dapat digunakan sebagai penelitian lebih lanjut untuk menentukan dosis efektif seduhan seledri. Sehingga untuk menguji dosis 160, $945 \mathrm{mg} /$ ekor/hari sebagai dosis efektif digunakan dosis sebesar $150 \mathrm{mg}$ sebagai dosis awal pada penelitian selanjutnya.

Sepanjang penelitian berlangsung selama 32 hari, semua tikus (25 ekor tikus) dapat mengikuti penelitian dari awal hingga akhir. Secara keseluruhan dari hasil penelitian ini diketahui bahwa induksi saripati hati ayam menyebabkan peningkatan kadar asam urat dan pemberian seduhan seledri dapat menurunkan kadar asam urat serum secara signifikan pada tikus yang diinduksi seduhan seledri selama 21 hari. Hal ini menunjukan bahwa flavonoid dan 3-n butilphthalide $(3 \mathrm{nB})$ bersifat antioksidan yang dapat mencegah produksi asam urat yang berlebihan pada tikus. Dengan demikian hasil penelitian sesuai dengan hipotesis yang diajukan yaitu pemberian seduhan seledri (Apium graveolens L.) dapat menurunkan kadar asam urat serum tikus putih (Rattus Norvegicus) hiperurisemia.

\section{SIMPULAN}

Berdasarkan hasil dan pembahasan dalam penelitian ini dapat ditarik kesimpulan bahwa pemberian seduhan seledri terbukti dapat menurunkan kadar asam urat serum pada tikus putih jantan (Rattus norvegicus) strain wistar yang diinduksi saripati hati ayam serta dosis air seduhan yang dapat menimbulkan efek secara nyata dimulai dari dosis 50 $\mathrm{mg}$ dan semakin besar penurunannya seiring dengan penambahan dosis.

\section{DAFTAR PUSTAKA}

\section{(Jurnal)}

Bell, N., Earl, J., Ford, J., Perry, L., Burnside, G., 2010. An Illustrated Companion to Pharmacology. Tha Kanji Foundry Press.

Bodamyali, T.J., Kanczler M., Millar T.M., Blake D.R., 2002. Free radicals in rheumatoid arthritis: Mediators and modulators In Redox Genomeinteractions in Health and Disease. Ed J. Fuchs, M.Podda, L.Packer.Marcel Dekker, New York.

Boyer, P.D., 1970. The Enzyme Kinetic and Mechanism. Academic Press.London 
Calkosinski I, Majda J, Borodulin-Nadzieja L, Wasilewska U, Standa M, Skalik R. 2004. Influence of acute pleuritis on lipid-cholesterol metabolism and blood concentration of sexual hormones in rats. Med Weter. 60: 990-993

Camire, 2005. Purine Metabolism \& Hyperuricemia. SOM/ WebResources-CaseWiki. (http:// wiki.case.edu. / SOM/Web Resources\& imgurl diakses tanggal 2 Desember 2010)

Chang, H.M., But, PPH. 1986. Pharmacologi and Applications of Chinese Materia Medica, Vol 2. World Scientific Publishing Co. Pte. Ltd. Singapore, pp 893-895.

Choi H.K., Mount D.B., Reginato A.M., 2005. Pathogenesis of Gout. Ann Intern Med. 143:499-516.

Cos, P et al. 1998. Structure-Activity Relationship and Classification of Flavonoids as Inhibitors of Xanthine Oxidase and superoxide Scavengers. J Nat Prod 61:7176

Dembinska-Kiec A, Naskalski J. 2002. Podstany z zakeresu diagnostyki lekarskiej. Diagnostyka laboratoryjna z. elementami biochemii klinicznej. 2nd ed., Elsevier Urban \& Partner, Wroclaw, Poland, pp 326, 29-47, 59-65.

Diagnostic Systems International, 2005, Diagnostic Reagent for Quantitative In Vitro Determination of Uric in Serum or Plasma on Photometric System. Holezhein: DyaSys Diagnostic System GmbH \& Co. KG.Germany.

Edwards NL. The role of hyperuricemia and gout in kidney and cardiovasculardisease. Cleve Clin J Med. 2008; 75 (suppl 5):S13-S16. Feldman BF, Zinkl JG, Nemi CJ. 2000. Schalm's Veterinary Hematology, $5^{\text {th }}$ ed., Lippincott Williams \& Wilkins, USA.

Fraser, CG. 2004. Inherent biological variation and reference values. Clin Chem Lab Med 42: 758-764.

Florakita, 2009, Tanaman Obat (Herbal) untuk Pengobatan. (http://www.duniaherbal.com/tanaman-obat-herbaluntuk-pengobatana-10.html diakses 27 Oktober 2010)

Hakim, L. 2002. Uji Farmakologi dan Toksikologi Obat Alam pada Hewan Coba. Prosiding Seminar Herbal Medicine Universitas Muhammadiyah Purwokerto: 1-21

Harris, Edward D., 2005. Kelley's Textbook of Rheumatology, 7 th ed. USA: Elsevier Science.

Hensen, Putra, T.R., 2007. Hubungan Konsumsi Purin dengan Hiperurisemia pada Suku Bali di Daerah Parinisata Pedesaan. Bali: Divisi Rematologi Imunologi Bagian / SMFIlmu Penyakit Dalam FK Unud/RS Sanglah.

Horton, H.R., Moran, L.A., Rawn, J.D., and Scrimgeour, K.G. 2002. Principles of Biochemistry. Prentise-Hall. Toronto

Indrawan IGNB. 2005. Hubungan Konsumsi Purin Tinggi dengan Hiperurisemia Studi Potong Lintang Analitik pada Penduduk Suku Bali di Kota Denpasar. Denpasar: In Press.

Ixoranet, 2007. Herbal seledri yang terkandung dalam tensicare. (http://www.ixoranet.com/ixonaret/ diakses tanggal 12 Februari 2011)

Jioa, R.H., Ge H.M., Shi D.A., Tan R.X., 2006. An ApegeninDerived Xanthine Oksidase Inhibitor from Palhinhae cernua. J Nat Prod 69:1089-1091

Johnstone, A., 2005. Gout - the disease and non-drug treatment. Hospital Pharmacist 12:391- 394.(lyrawati.files. wordpress.com/2008/11/gout_obat_hosppharm.pdf. 25 november 2009)
Kristanti, N., 2003. Phaleria papuana, si Alternatif bagi Asam Urat. (http://pasti.itgo.com/ diakses 22 oktober 2009) Kelly WN, Wortmann RL. Crystal-associated synovitis: gout and hyperuricemia. In: Kelly WN, Harris ED, Ruddy S, Sledge CB, editors. Textbook of Rheumatology. 5 thed. Philadelphia: WB Saunders: 1997.p.131347.

Lippi G, Franchini M, Montagnana M, Salvagno GL, Poli G, Guidi GC. 2006. Quality and reliability of routine coagulation testing: can we trust that sample? Blood Coagul Fibrinolysis 17: 513-519.

Malole MBM, Pramono CSU. 1989. Penggunaan HewanHewan Percobaan di Laboratorium. Bogor: Departemen Pendidikandan Kebudayaan Direktorat Jendral Pendidikan Tinggi Pusat Antar Universitas Bioteknologi Institut Pertanian Bogor. Hal: 104-112.

Massey V., Koami H., Palmer G., Elion, G.B., 1970. J Biol Chem 245:2837-2844.

Mellado, Vazquez, J., morales, Meono, E., Pacheco-Tena, C., 2001. Relation Between Adverse Events Associated with Allopurinol and Renal Function in Patients with Gout. Am Rheum Dis. Vol. 60, p. 981-983.

Millar, T.M. et al, 2002. Xanthine oxidase is a peroxynitrite synthase newly identified roles for a very old enzyme. Redox Report 7(2):65-70

Murray, M., 2004. Celery Seed Extract. (http:// www.myhealthmybody.com/trellis / ADM4515\% 20Celery\%20Seed.Diakses tanggal 3 April 2010)

Nan H, Qing Qiao, Yanhu Dong, Weiguo Gao, Bin Tang, Rongli Qian, et al. The prevalence of hyperuricemia in a population of the Coastal City of Qingdao, China. J Rheumatol 2006; 33:1346-50

Neumeister B, Besenthal I, Liebich H. 2001. Diagnostyka laboratoryjna, $1^{\text {st }}$ ed., Elsevier Urban \& Partner, Wroclaw, Poland.

Perry, L.M, 1980. Medical Plants of East and Southeast Asia: Attributed, Properties, and Uses. The MIT Press. Massachusetts, pp 413.

Putra, I.B., 2008. Indometasin sebagai Terapi Gout Arthritis. (http://www.scribd.com/doc/12363563/Indomethacin-for-gout-arthritisTherapy diakses tanggal 27 April 2010).

Reynertson, K.A., 2007, Phytochemical Analysis of Bioactive Constituens from Edible Myrtaceae Fruit, Dissertation, The City University of New York, New York.

Rosy, T. dan Mulyani, S., 2009. One way ANOVA. (http:/ /www.scribd.com/ doc/47922880/One-Way-Anova diakses tanggal 17 januari 2011)

Syarifudin, M., 2010. Teh Hijau Tjimapag. (http:// pecinta_teh@yahoogroups.com diakses tanggal 31 Januari 2011)

Shull BC, Lees H, Li PK. 1980. Mechanism of interference by hemoglobin in the determination of total bilirubin. I. Method of Malloy-Evelyn. Clin Chem 26: 22-25.

Sturm, N. 2008. Purin Metabolism. (http:// chemistry.gravitywaves.com/ CHEMXL153/Purine Metabolism.htm diakses tanggal 31 Desember 2010) Sudarsono, Pudjoanto, A., Gunawan, D., Wahyuono, S., Donatus, I. A., Drajad, M., Wibowo, S., dan Ngatidjan, 1996, Tumbuban Obat, Hasil Penelitian, Sifat-sifat dan 
Penggunaan, 44-52, Pusat Penelitian Obat Tradisional, UGM, Yogyakarta (http://ccrc.farmasi.ugm.ac.id/ ?page_id=584 diakses tanggal 4 Juni 2009)

Suprapto, J., 2007. Teknik Sampling Survey \& Eksperimen. Rineka Cipta, Jakarta.

Taconic Technical Laboratory, 1998. Hematological and Clinical Chemistry Values Wistar Rats (http:/ www.taconic.com/healthr/hematology/wkheme.htm diakses tanggal 27 Desember 2009)

United States Departement Of Agriculturale (USDA) National Nutrient Database for Standard Reference. 2010. Celery, raw. (http://www.nal.usda.gov/ fnic/ foodcomp/cgi-bin/list_nut_edit.pl diakses tanggal 26 Februari 2011)

Wichtl, M., 1994. Herbal Drug and Phytopharmacochemistry. MedPhar Scientific Publisher. CRC Press, pp 81-82

Wisesa, I.B.N., Suastika, K., 2009. Hubungan antara Konsentrasi Asam Urat Serum dengan Resistensi Insulin pada Penduduk. Suku Bali Asli di Dusun Teganan Pegringsingan Karangasem (http://ejournal.unud.ac.id /abstrak/ 4_dr $\% 20 \mathrm{ib} \% 20$ wisesa.pdf diakses tanggal 1 Desember 2010)

Wortmann, R.L., 2009. Gout and Hyperuricemia Dalam Firestein G.S, Budd R.C, Harris E.D, Rudy S, Sergen JS (Ed) Kelley Textbook of Rheumatology. 8 thed. Philadelphia: Sunders. P 1481-506

Zwaving, 1989. Mid Careertraining in Pharmacochemistry. Joint Project between Fakultas Farmasi UGM, Yogyakarta and the Departement of Pharmacochemistry Vrij Universiteit Amsterdam, pp 46-47.

\section{(Buku)}

Amstrong, F.B., 1995. Buku Ajar Biokimia. Jakarta: Penerbit Buku Kedokteran EGC.

Ashari, S., 1985. Teknologi Buah Dan Sayur. Bandung: Penerbit Alumni.

Dalimarta, S., 2000. Atlas Tumbuhan Obat Indonesia Jilid II. Jakarta: PT. Trubus Agriwidya. Hal 172.

Duke, J.A., 1985. CRC-Handbook of Medical Herbs. CRC Press Inc., Boca Raton., pp 45-46.

Katzung, B.G., 2002. Farmakologi Dasar dan Klinik. Jakarta: Penerbit Salemba Medika.

Kusumawati, diah. 2004. Bersahabat Dengan Hewan Coba. Yogyakarta: Gadjah Mada University Press.

Martin, D.W. 1992. Metabolisme Nukleotida Purin dan Pirimidin dalam Biokimia Harper. Penerbit Buku Kedokteran EGJ. Jakarta.

Mycek, M.J., Harvey R.A., Champe P.C., 2001. Farmakologi: Ulasan Bergambar. Ed.ke-2 Agoes A, penerjemah. Jakarta: Widya Medika.

Putra, T.R., 2007. Reumatologi Hiperurisemia Dalam A.W Sudoyo, B. Setiyohadi, I. Alwi, Marcullus S.K., S. Setiadi (Ed) Buku Ajar Ilmu Penyakit Dalam Jilid I Edisi IV. Jakarta: Pusat Penerbit Departemen Ilmu Penyakit Dalam Fakultas Kedokteran Universitas Indonesia.

Price, N.C., Stevens L., 1996. Fundamental of enzymology 2 xx nd Edition. New York: Oxfort University Press.

Robinson R. 1979. Taxonomy and Genetic. In The Laboratory Rat. Volume 1. Biology and Disease. Edt ; Baker J. Henry, et al. San Fransisco: Academic Press. Pp: 38.
Roefiq, A, 2001. Metode Penelitian. Malang : UMM Press. Rodwell, V.R. 2003. Struktur, Fungsi, dan Replikasi Makromolekul Informasi Metabolisme Nukleotida Purin dan Pirimidin. Dalam: R. K. Murray, D.K. Granner, P. A. Mayes, V. R. Rodwell (Ed) Biokimia Harper. Diterjermahkan oleh: Andry Hartono. Penerbenit Buku Kedokteran EGC, Jakarta.

Smith JB, S. Mangkoewidjojo. 1998. Pemeliharaan, Pembiakan, dan Penggunaan Hewan Percobaan di Daerah Tropis. Jakarta: UI Press. Hal: 37-38

dan Sulaksono ME. 1997. Pengaruh Faktor Keturunan dan Lingkungan Terhadap Sifat-sifat Biologis Yang Terlihat pada Hewan Percobaan. Departemen Kesehatan Republik Indonesia. Badan Penelitian dan Pengembangan Kesehatan. Jakarta: Media Penelitian dan Pengembangan Kesehatan. VII.1.

Sulaksono ME, Pudjoprajitno, Yuwono SS dan Patra K. 1986. Keadaan dan Masalab Hewan Percobaan di Indonesia. Departemen Kesehatan Republik Indonesia. Badan Penelitian dan Pengembangan Kesehatan. Jakarta: Buletin Penelitian Kesehatan. 